\title{
UJI CEMARAN AIR MINUM MASYARAKAT SEKITAR MARGAHAYU RAYA BANDUNG DENGAN IDENTIFIKASI BAKTERI Escherichia coli
}

\author{
Susi Afrianti Rahayu, Muhammad Hidayat Gumilar \\ Program Studi D3 Farmasi, Akademi Farmasi Bumi Siliwangi \\ Jl. Rancabolang No. 48 B Margahayu Raya Bandung 40286
}

\begin{abstract}
ABSTRAK
Air merupakan kebutuhan manusia yang paling penting. Agar tetap sehat, air minum harus memenuhi persyaratan fisik, kimia maupun bakteriologis. Penelitian ini bertujuan untuk memeriksa cemaran Air Minum Dalam Kemasan (AMDK), Air Minum Isi Ulang (AMIU), dan air dengan alat Pemurnian (Purrified) di masyarakat sekitar jalan Merkuri Timur, Margahayu Raya Bandung. Penelitian ini dilakukan dengan mengidentifikasi bakteri Escherichia coli pada air minum. Metode tersebut menggunakan angka lempengan total (ALT), Pewarnaan Gram, Pewarnaan Kapsul, Pewarnaan Tahan Asam, Uji Indol, Metil Merah, Voges Proskauer, Sitrat (IMViC) dan uji fermentasi gula. Dari 5 sampel yang diuji, ke-5 sampel tersebut tidak memenuhi syarat menurut SNI serta PERMENKES karena mengandung jumlah bakteri yang melebihi batas maksimal yaitu 1,0 x $10^{2}$ untuk cemaran mikroba dan 0 koloni/g (per $100 \mathrm{ml}$ sampel) untuk bakteri Escherichia coli . Dari 5 sampel tersebut 2 sampel teridentifikasi bakteri Escherichia coli sementara 3 sampel lainnya mengandung bakteri koliform yang lain.
\end{abstract}

Kata Kunci : Cemaran, AirMinum, Escherichia coli

\section{TEST OF DRINKING WATER AROUND MARGAHAYU RAYA BANDUNG WITH IDENTIFICATION OF Escherichia coli BACTERIA}

\begin{abstract}
Water is the most important human need. In order to stay healthy, drinking water must meet the physical, chemical and bacteriological requirements. This study aimed to examine the contamination of drinking water (AMDK), drinking water refill (AMIU), and purifying water in the community around Merkuri Timur street, Margahayu Raya Bandung. This research used identification method of Escherichia coli bacteria. The total plate count (ALT), gram staining, capsule staining, acid-resistant staining, Indole Test, Methyl Red, Voges Proskauer, Citrate (IMViC) and sugar fermentation test methods were used in this study. From 5 samples tested, the 5 samples were not qualified according to SNI and PERMENKES because it contains bacteria that exceeds the maximum limit of $1.0 \times 102$ for microbial contamination and 0 colony / g (per $100 \mathrm{ml}$ sample) for Escherichia coli bacteria. Of the 5 samples, 2 samples identified Escherichia coli bacteria while 3 other samples contain other coliform bacteria.
\end{abstract}

Keywords: contamination, drinking water, Escherichia coli 


\section{Pendahuluan}

Air merupakan kebutuhan manusia yang paling penting. Kadar air tubuh manusia mencapai $68 \%$ dan untuk tetap hidup kadar air dalam tubuh harus dipertahankan. Kebutuhan air minum setiap orang bervariasi mulai dari 2,1 liter hingga 2,8 liter perhari, tergantung pada berat badan dan aktivitasnya. Agar tetap sehat, air minum harus memenuhi persyaratan fisik, kimia maupun bakteriologis. ${ }^{29}$

Batas maksimal cemaran mikroba yang diizinkan dalam Kualitas air minum menurut PerMenKes No.492/ Menkes /Per/IV/2010 berdasarkan kualitas mikrobiologisnya yaitu: Total bakteri Escherichia coli maksimal 0 koloni/g (per $100 \mathrm{ml}$ sampel) dan Total bakteri Coiliform maksimal 0 koloni/g (per $100 \mathrm{ml}$ sampel). ${ }^{16}$

Cemaran mikroba merupakan mikroba yang keberadaannya dalam pangan pada batas tertentu dapat menimbulkan risiko terhadap kesehatan Terdapatnya mikroba di dalam bahan pangan yang dianggap sebagai cemaran ialah apabila mikroba tersebut dapat mengakibatkan menurunnya mutu makanan/minuman, rusaknya bahan dan mengakibatkan gangguan pada kesehtan manusia. $^{2}$

Escherichia coli merupakan bakteri komensal yang dapat bersifat patogen, bertindak sebagai penyebab utama morbiditas dan mortalitas di seluruh dunia.

Salah satu metode yang dapat mengidentifikasi suatu bakteri ialah Pewarnaan Gram, Pewarnaan Kapsul dan Pewarnaan Tahan Asam. Pewarnaan Gram merupakan pewarnaan diferensial yang sangat berguna dan paling banyak digunakan dalam laboratorium mikrobiologi ${ }^{14}$. Pewarnaan kapul adalah teknik yang digunakan untuk mengetahui suatu bakteri memilik kapsul pada tubuhnya. Kapsul adalah lapisan polimer yang terdapat diluar dinding sel ${ }^{(9)}$. Pewarnaan Tahan Asam merupakan salah satu metode untuk mengidentifikasi bakteri tahan asam. Bakteri tahan asam merupakan bakteri yang kandungan lemaknya sangat tebal sehingga tidak bisa diwarnai dengan reaksi pewarnaan biasa, tetapi harus dengan pewarnaan tahan asam. ${ }^{14}$

Uji biokimia bakteri merupakan suatu cara atau perlakuan yang dilakukan untuk mengidentifikasi dan mendeterminasi suatu biakan murni bakteri hasil isolasi melalui sifat-sifat fisiologinya. Proses biokimia erat kaitannya dengan metabolisme sel, yakni selama reaksi kimiawi yang dilakukan oleh sel yang menghasilkan energi maupun yang menggunakan energi untuk sintesis komponen-komponen sel dan untuk kegiatan seluler, seperti pergerakan. ${ }^{9}$

\section{Metode}

\section{Alat dan bahan}

Mikroskop binokuler XSZ 107BN ;Jarum Ose ;Cawan Petri (Pyrex) ;Bunsen ;Kapas ;Pipet tetes ;Erlenmeyer (Pyrex) ;Beaker glass (Pyrex) ; Magnetic Stirrer SSM 79-1 ;Inkubator (Kenako) ;Colony Counter type J-3 ;Objek glass (Slides) ; Autoklaf type XYQG;Tabung reaksi (Pyrex) Sampel Air Minum ;Nacl 0,9\% ;Nutrient Agar (Merck) ; Escherichia coli (ATCC 25922) ;Media Glukosa, Laktosa ,Sakarosa (Merck) ;Kristal Violet ;Safranin ;Tinta Cina ;Alkohol 70\% (Medika) ;Aquadest ;Larutan HCL-Alkohol (1:1) ;Larutan Lugol ; Simon Sitrat Agar (Merck) ;Media tryptone broth; glucose phosphate broth (Himedia);Minyak Imersi (Merck) ; Pereaksi Indol ; Larutan Naftol ; Larutan $\mathrm{KOH} 40 \%$;Larutan Metil Biru ; Larutan Karbol Fuchin

\section{Pengambilan Sampel}

Sampel air minum diperoleh dari masyarakat sekitar jalan Merkuri Timur, Margahayu Raya Bandung. Dari total keseluruhan penduduk berjumlah 64 rumah, maka didapat data sampel air minum sebagai berikut : 
Tabel 1 Klasifikasi sampel uji air minum

\begin{tabular}{ll}
\hline Jenis Air minum & Jumlah \\
\hline AMDK (A) & 44 \\
AMDK (B) & 2 \\
AMDK (C) & 7 \\
AMIU (D) & 10 \\
Purified Water (E) & 1 \\
\hline
\end{tabular}

Masing-masing sampel uji diencerkan dengan cara sampel dikocok lalu dipipet sebanyak $1 \mathrm{ml}$ kedalam tabung reaksi berisi $9 \mathrm{ml} \mathrm{Nacl} 0,9 \%$ aduk sampai homogen sehingga didapatkan pengenceran $10^{-1}$. Selanjutnya dilakukan secara serial sehingga didapatkan pengenceran $10^{-2}$ dan seterusnya sampai $10^{-6}$. Sampel uji ditumbuhkan pada medium Nutrien Agar (NA) dengan cara memasukkan $1 \mathrm{ml}$ sampel kedalam cawan yang berisi $19 \mathrm{ml}$ Nutrien Agar (NA) kemudian cawan digoyangkan dengan maksud agar sampel tercampur dengan media Nutrient Agar. Sampel diinkubasi pada suhu $37^{\circ} \mathrm{C}$ selama 48 jam (18).

\section{Pengujian Angka Lempengan Total}

Dihitung koloni pada cawan perti dengan koloni antara 30-300. Cawan diletakkan secara terbalik lalu dihitung menggunakan alat Colony Counter Dengan alat perhitungan mekanis ditangan, Jumlah koloni dihitung dari baris keatas secara horizontal, pada baris dibawahnya dan seterusnya. Jumlah koloni dikalkulasikan per ml biakan menggunakan rumus :

$\operatorname{ATL}\left(\frac{\text { Koloni }}{m l}\right)=\frac{\text { koloni }}{\text { faktor pengencer } x \text { ml inokulan }}$

\section{Identifikasi Bakteri Escherichia coli}

Masing-masing inokulan sampel uji diambil dari stok kultur biakan dengan menggunakan jarum Ose steril, kemudian disuspensikan ke dalam $10 \mathrm{ml}$ larutan $\mathrm{NaCl}$ steril lalu dikocok sampai didapat larutan kekeruhan. ${ }^{4}$ Untuk selanjutnya dilakukan pengujian pewarnaan gram, kapsul, tahan asam, dan uji biokimia.

\section{Hasil dan Pembahasan}

\section{Pengujian Angka Lempengan Total}

Pada perhitungan koloni, berdasarkan data dari setiap sampel hanya dihitung pengenceran dengan jumlah koloni antara 30-300. Hal ini bertujuan untuk memperkecil kemungkinan kesalahan dalam perhitungan. Karena percobaan dilakukan dua kali (duplo) maka harus menggunakan data dari kedua pengulangan dengan cara mengambil rata-rata dari kedua data, dihitung dan dibandingkan dengan standar uji cemaran mikroba untuk air minum. ${ }^{1}$

Tabel 2 Hasil pengujian angka lempengan total

\begin{tabular}{cccc}
\hline Sampel & $\begin{array}{c}\text { Angka } \\
\text { Lempengan } \\
\text { Total } \\
\text { (koloni/ml) }\end{array}$ & $\begin{array}{c}\text { Standar } \\
(\text { Koloni/ml) }\end{array}$ & Keterangan \\
\hline A & $8,6 \times 10^{4}$ & $1,0 \times 10^{2}$ & TMS \\
B & $8,0 \times 10^{4}$ & $1,0 \times 10^{2}$ & TMS \\
C & $6,4 \times 10^{4}$ & $1,0 \times 10^{2}$ & TMS \\
D & $4,2 \times 10^{4}$ & $1,0 \times 10^{2}$ & TMS \\
E & $7,2 \times 10^{4}$ & $1,0 \times 10^{2}$ & TMS \\
\hline
\end{tabular}

TMS = Tidak Memenuhi Syarat

Karena jumlah koloni pada setiap sampel dengan pencenceran $10^{-6}<30$, maka peneliti menetapkan nilai ALT dipilih dari pengenceran terendah yaitu $10^{-3}$. Hal ini dikarenakan peneliti telah melakukan uji pendahuluan terhadap sampel yang akan digunakan dalam pengujian ALT ini. Pada sampel dengan pengenceran $10^{-3}$ terlihat jumlah koloni yang bisa dihitung antara 30300 koloni. Sedangkan pada pengenceran diatas $10^{-3}$ koloni sulit untuk dihitung, dan pada pengenceran dibawah $10^{-3}$ jumlah koloni $<30$.

\section{Uji Blangko Pada Bakteri Escherichia coli}

Pewarnaan Gram terhadap bakteri Escherichia coli menunjukan bahwa bakteri berbatang pendek dan berwarna merah setelah proses pewarnaan. Hal ini disebabkan karena konsentrasi lipid dan ketebalan lapisan peptidoglikan pada dinding sel bakteri. Dengan kata lain bakteri 
Escherichia coli merupakan bakteri Gram negatif. Pada sel Gram negatif, alkohol meningkatkan porositas dinding sel dengan melarutkan lipid lapisan luar. Jadi, kompleks Kristal Violet (KV-I) dapat lebih mudah dihilangkan dari lapisan peptidoglikan yang tidak tertaut silang dengan kuat. Oleh sebab itu, efek pencucian alkohol memfasilitasi pelepasan kompleks KV-I yang tidak terikat, yang membuat selsel menjadi kehilangan warna atau tidak berwarna. Karena hanya sel-sel Gram negatif yang mengalami kehilangan warna sehingga sel-selnya menyerap pewarna tandingan. Sedangkan Gram-positif mempertahankan warna ungu dari pewarna primer. ${ }^{19}$

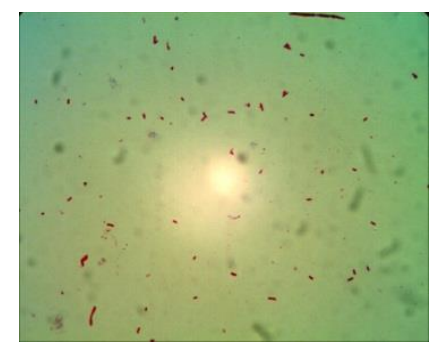

Gambar 1 Hasil Pewarnaan Gram bakteri Escherichia coli

Hasil pewarnaan kapsul terhadap bakteri Escherichia coli menunjukan bahwa bakteri tersebut terwarnai dengan warna merah. Prinsip dasar pewarnaan kapsul ialah kapsul pada kuman tidak dapat mengikat zat warna, sehingga pada pemberian cat tinta cina dan carbol fuksin terlihat bulatan terang atau transparan dengan latar belakang gelap dan badan kuman berwarna merah dari fuchsin. ${ }^{13}$

Gambar 2 Hasil Pewarnaan Kapsul bakteri Escherichia coli

Hasil pewarnaan tahan asam terhadap bakteri Escherichia coli menujnukan bahwa bakteri tersebut terwarnai dengan warna biru, sehingga dapat dikatakan bahwa bakteri Escherichia coli tidak termasuk bakteri tahan asam. Prinsip dari pewarnaan tahan asam ialah dinding bakteri yang tahan asam mempunyai lapisan lilin dan lemak yang sukar ditembus cat. Oleh karena dengan pengaruh pemanasan, maka lapisan lilin dan lemak itu dapat ditembus cat basic fuchsin. Pada waktu pencucian lapisan lilin dan lemak yang terbuka akan merapat kembali. Pada pencucian dengan asam alkohol warna fuchsin tidak dilepas. Sedangkan pada bakteri tidak tahan asam akan luntur dan mengambil warna biru dari methylen blue. ${ }^{22}$

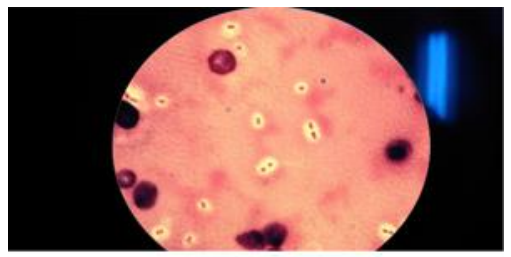

Gambar 3 Hasil Pewarnaan Tahan Asam bakteri Escherichia coli

\section{Uji Biokimia (Uji IMViC \& Uji Gula)}

Uji indol bertujuan mengidentifikasi kemampuan bakteri menghasilkan indol dengan menggunakan enzim tryptophanase. Produksi indol di dalam media dimungkinkan karena adanya tryptophan. Tryptophan adalah asam amino esensial, yang teroksidasi oleh beberapa bakteri yang mengakibatkan pembentukan indol, asam piruvat, dan amonia ${ }^{(10)}$. Hasil uji Indol pada bakteri Escherichia coli adalah positif yang ditunjukan adanya cincin merah pada bagian atas, hal ini disebabkan karena indol bereaksi dengan aldehid. $^{25}$ Namun karena cincin mudah memudar oleh gerakan yang tiba-tiba,

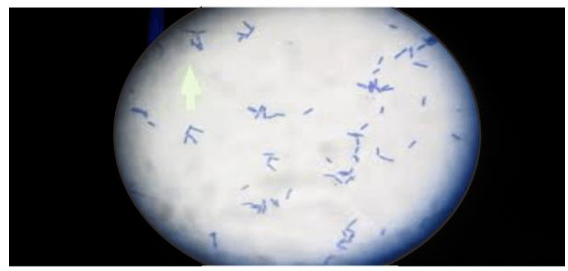

cincin menjadi pecah dan menghasilkan warna merah muda.

Uji Methyl Red (MR), bertujuan untuk mendeteksi kemampuan organisme dalam memproduksi dan mempertahankan produk akhir asam stabil dari fermentasi glukosa. Methyl red adalah indikator $\mathrm{pH}$, yang tetap berwarna merah pada $\mathrm{pH} 4,4$ atau kurang. ${ }^{25}$ Hasil pengamatan untuk uji MR pada isolat 
bakteri Escherichia coli adalah positif yang ditunjukkan dengan larutan berwarna merah.

Uji Voges Proskauer (VP) adalah tes yang digunakan untuk mendeteksi acetonin dalam kultur cair bakteri. Pengujian ini dilakukan dengan menambahakan alphanaftol dan kalium hidroksida dengan kaldu voges Proskauer yang telah diinokulasi dengan bakteri. Warna merah menunjukkan hasil yang positif, sedangkan warna kuningcoklat atau tidak berwarna merupakan hasil negative. ${ }^{25}$ Uji ini negatif untuk Escherichia coli karena Escherichia coli memfermentasikan karbohidrat menjadi produk asam dan tidak menghasilkan produk netral seperti asetonin.

Uji sitrat bertujuan mendeteksi kemampuan suatu organisme untuk memanfaatkan sebagai satu-satunya sumber karbon dan energi. Jika bakteri mampu menggunakan sitrat sebagai sumber karbonnya maka akan menaikan $\mathrm{pH}$ dan mengubah warna medium biakan dari hijau menjadi biru. ${ }^{25}$ Hasil pengamatan untuk uji sitrat adalah negatif pada Escherichia coli yang ditujukan tidak adanya perubahan warna pada media uji sitrat. Escherichia coli merupakan salah satu bakteri yang tidak menggunakan sitrat sebagai sumber karbon dilingkungan. ${ }^{25}$

Pada uji fermentasi gula pada bakteri Escherichia coli menunjukan bahwa Escherichia coli dapat memfermentasikan laktosa, glukosa dan sakarosa serta menghasilkan hidrogen sulfida $\left(\mathrm{H}_{2} \mathrm{~S}\right)$. Hal itu ditandai dengan perubahan warna dari merah menjadi kuning, serta adanya gelembung pada media gula. Sedangkan pada media sakarosa ditandai dengan warna tetap menjadi merah.

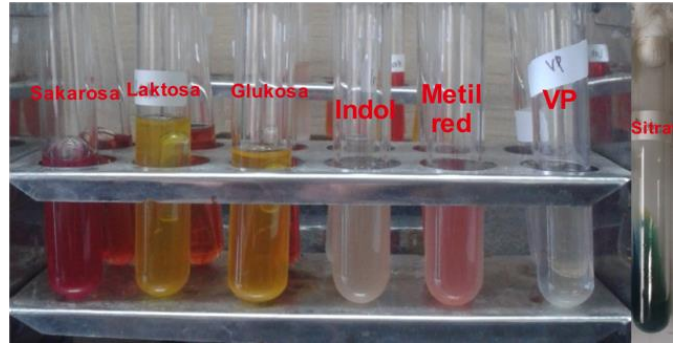

Gambar 4 Hasil uji Biokimia bakteri Escherichia coli
Dari pemaparan di atas, dapat disimpulkan sebagai berikut :

Tabel 3 Hasil Pengujian Bakteri

Escherichia coli

\begin{tabular}{ll}
\hline $\begin{array}{l}\text { Karakteristik } \\
\text { Pengujian }\end{array}$ & Jenis Isolat \\
\hline Pewarnaan Gram & Gram Negatif \\
Pewarnaan Kapsul & + \\
& merah) \\
Pewarnaan Tahan Asam & - \\
Indole & + \\
MR & + \\
VP & - \\
Sitrat & - \\
Media Glukosa & + \\
Media Laktosa & + \\
Media Sakarosa & + \\
\hline
\end{tabular}

\section{Hasil Pengujian pada sampel}

Pada tabel 4 dilihat untuk uji biokimia, karakteristik sampel A cocok dengan karakteristik blangko Escherichia coli, hal ini menandakan bahwa sampel A tercemar bakteri Escherichia coli. Untuk sampel B pada pengujian biokimia 1 pengujian yaitu pengujian sitrat menunjukan hasil yang berbeda dengan blangko Escherichia coli, sama dengan penelitian yang dilakukan oleh Zulfikar (2015) bahwa sampel menunjukkan hasil yang sama, maka sampel tercemar bakteri Escherichia coli sitrate positive. Untuk sampel $\mathrm{C}, \mathrm{D}$, dan $\mathrm{E}$ hasil yang didapat rata-rata 3-4 perbedaan hasil pengujian dengan blangko Escherichia coli, dimana perbedaan yang sangat mencolok yaitu hasil ketiga sampel tersebut negatif pada uji fermentasi gula. Ada kemungkinan sampel terkontaminasi dengan bakteri yang tidak dapat memfermentasi gula, sehingga hasil yang didapat tidak sesuai dengan blangko, menurut Hemraj (2013) terdapat salah saktu bakteri yang tidak memiliki kemampuan memfermentasi gula. Bakteri tersebut adalah bakteri dengan genus Shigella. Shigella merupakan bakteri Gram negatif anggota dari kelompok bakteri coliform yang sering mencemari air. Oleh karena itu ada kemungkinan sampel terkontaminasi oleh jenis bakteri tersebut 
Tabel 4 Hasil Pengujian Sampel

\begin{tabular}{|c|c|c|c|c|c|c|}
\hline $\begin{array}{c}\text { Karakteristik } \\
\text { pengujian }\end{array}$ & $\begin{array}{c}\text { Sample } \\
\text { A }\end{array}$ & $\begin{array}{c}\text { Sample } \\
\text { B }\end{array}$ & $\begin{array}{c}\text { Sample } \\
\text { C }\end{array}$ & $\begin{array}{c}\text { Sample } \\
\text { D }\end{array}$ & $\begin{array}{c}\text { Sample } \\
\text { E }\end{array}$ & $\begin{array}{c}\text { Blangko } \\
\text { E.coli }\end{array}$ \\
\hline P. Gram & Gram - & Gram - & Gram - & Gram - & Gram - & Gram - \\
\hline P. Kapsul & + & + & + & + & + & + \\
\hline P. Tahan Asam & - & - & - & - & - & - \\
\hline Indole & + & + & + & + & + & + \\
\hline MR & + & + & + & + & + & + \\
\hline VP & - & - & - & - & - & - \\
\hline Sitrat & - & + & + & - & - & - \\
\hline Media Glukosa & + & + & - & - & - & + \\
\hline Media Laktosa & + & + & - & - & - & + \\
\hline Media Sakarosa & + & + & - & - & + & + \\
\hline
\end{tabular}

\section{Simpulan}

Berdasarkan hasil penelitian, dapat disimpulkan bahwa :

Dari 5 sampel air minum yang diuji, ke-5 sampel tersebut tercemar oleh bakteri, dimana 2 diantaranya terindentifikasi bakteri Escherichia coli. Sehingga semua sampel air minum tidak memenuhi standar menurut Standar Nasional Indonesia (SNI) 01-3553-2006 tentang Kriteria air Minum serta menurut Peraturan Menteri Kesehatan Republik Indonesia No. 492/Menkes/Per/IV/2010 tentang kadar maksimum bakteri Escherichia coli di dalam air minum.

Terdapat cemaran bakteri lain selain bakteri Escherichia coli yang terkandung didalam 3 sampel lainnya. Kemungkinan cemaran tersebut adalah bakteri genus Shigella.

\section{Daftar Pustaka}

1. Andrian G., 2014 Analisis cemaran bakteri coliform dan identifikasi escherichia coli pada air minum isi ulang dari depot di kota Manado, Jurnal ilmiah farmasi. 3(3) : 325-334

2. BSNI (Badan Standarisasi Nasional Indonesia), 2009. Tentang Cemaran Mikroba: Badan Standarisasi Nasiona Indonesial. Hal. 3-5

3. Depkes RI, 2006. Pedoman Pelaksanaan Penyelenggaraan Hygene
Sanitasi Depot Air Minum, Dirjen Penyehatan Lingkungan, Jakarta

4. Ditjen POM. 1995. Materia Medika Indonesia. Jilid VI. Jakarta: Departemen Kesehatan RI. Hal. 173176.

5. Dwidjoseputro. 1978. Dasar-Dasar Mikrobiologi. Jakarta: Djambatan.

6. Fardiaz. S., 1993. Analisi Mikrobiologi Pangan. Jakarta : PT Gramedia Pustaka Utama

7. Garcia, H.H., Evans, C.A.W., Nash, T.E., Takayanagui, O.M., White, A.C., Botero, D., et al., 2002. Current Consensus Guidelines for Treatment of Neurocysticercosis. American Society for Microbiology 15 (4): 747-756

8. Geo FB, Karen CC, Janet SB, Stephen AM, Timothy AM, 2011. Medical Microbiology 25th edition, New York: McGraw Hill.

9. Hadiutomo, 1990. Mikrobiologi Dasar Jilid I. Jakarta: Erlagga.

10. Hemraj, V., 2013. A review on Commonly Used Biochemical Test For Bacteria. India: Departement of Pharmacy, L R Intitute of Pharmacy, Solan (H.P).

11. Jawetz M, Melnick R, Adelberg, 2008. Mikrobiologi Kedokteran. Jakarta: EGC. P 199-200

12. Jawetz, E. et al. 1995. Review of Medical Microbiology. Los Altos, California: Lange Medical Publication. Pages 227-230 
13. Kumar, V., Cotran, R.S., dan Robbins S.L., 2007. Buku Ajar Patologi. Edisi 7; ali Bahasa, Brahm U, Pendt ;editor Bahasa Indonesia, Huriawati Hartanto, Nurwany Darmaniah, Nanda Wulandari.-ed.7-Jakarta: EGC.

14. Lay, B.W. 1996. Analisis Mikroba di Laboratorium. Jakarta: Raja Grafindo Persada. Hal. 57-58, 109.

15. Menteri Kesehatan Republik Indonesia. Persyaratan Kualitas Air Minum. Dalam Permenkes RI Nomor 492/PERMENKES/PER/IV/2010.

Jakarta: Menkes RI; 2010. Diakses pada tanggal 16 Desember 2016 dari http://pppldepkes.go.id/_asset/_regulasi 153_permenkes\%20492.

16. Nugroho, Dimas. (2015) Uji Mikrobiologis Pada Berbagai Jenis Air Minum. Skripsi. Fakultas Kedokteran dan Kesehatan Universitas Islam Negeri Syarif Hidayatullah, Jakarta.

17. Oxoid. 1998. The Oxoid Manual. Edisi VIII. Basingstoke: Oxoid Limited.

18. Parija, S.C., 2009, Textbook of Microbiology and Immunology, 71-73, Elsevier India Pvt. Ltd., India.

19. Post, K W. and Songer, GJ. 2005. MICROBIOLOGY Bacterial and Fungal Agent of Animal Disease. Elsevier Saunders: Philadelphia.

20. Pratiwi, S. 2008. Mikrobiologi Farmasi. Jakarta: Erlangga.

21. Sechlegel, H. G. And Schimt, K. 1994. Mikrobiologi Umum. Yogyakarta : UGM Press.

22. Setiabudy, R., Gan, V. H. 2007. Pengantar Antimikroba. Dalam: Farmakologi dan Terapi Edisi 5. Gaya Baru, Jakarta.

23. Soemirat, Juli, 2006. Kesehatan Lingkungan, Gajah Mada University Press, Yogyakarta.

24. Sridhar, 2006. IMVic Test Prosedure. Diakses pada 7 Juli 2017 dari www.microrao/commontnote.

25. Sunarjo, 1994. Penyehatan Air dalam Program Penyediaan dan Pengolahan Air Bersih. Jakarta
26. Standar Nasional Indonesia, 2014. Batas Maksimum Cemaran Mikroa Dalam Air Minum. Jakarta: Badan Standarisasi Andalas.

27. Suprihatin, 2003. Hasil Studi Kualitas Air Minum Depot Isi Ulang. Makalah pada Seminar Sehari Permasalahan Depot Air Minum dan Upaya Pemecahannya. 7 Juli 2003, Bandung.

28. Suriawiria, U. 2006. Mikrobiologi Air. PT Alumni: Bandung.

29. Tria, Zulfikar Raharja. (2015). Identifikasi Escherichia coli pada air minum isi Ulang dari Depot di Kelurahan Pisangan dan Cirendeu Tahun 2015. Skripsi. Fakultas Kedokteran dan Kesehatan Universitas Islam Negeri Syarif Hidayatullah, Jakarta

30. World Health Organization Articel Journal Dalam: Diarrhea disease Geneva: WHO; 2013. Diakses pada tanggal 16 Desember 2016 dari http://www.who.int/mediacentre/facthe ets/fs330/en/

31. Yuli Pratiwi, 2014. Pemeriksaan Bakteriologis Air Munim Dari Depot Air Minum Isi Ulang. Prosiding Seminar Nasional Aplikasi Sains \& Teknologi (SNAST) 2014. 15 November 2014, Yogyakarta. Hal 315322. 